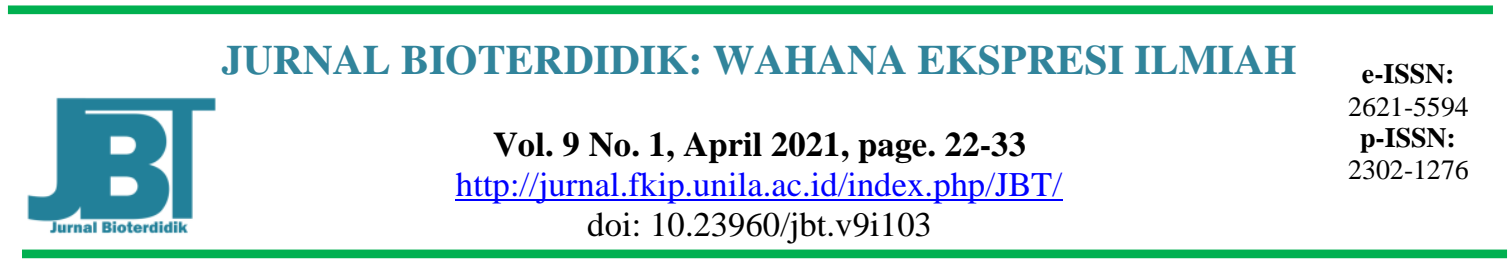

\title{
Analisis Manajemen Pembelajaran Online Berbasis Media Sosial WhatsApp untuk Meningkatkan Motivasi dan Hasil Belajar Siswa Materi Sistem Pencernaan
}

\author{
Mieke Nurhayati ${ }^{1}$, Dakir ${ }^{1}$, Noor Hujjatusnaini ${ }^{2 *}$ \\ ${ }^{1}$ Manajemen Pendidikan Islam. Pascasarjana IAIN Palangka Raya. Indonesia. \\ ${ }^{2}$ Program Studi Tadris Biologi. Fakultas Tarbiyah dan Ilmu Keguruan. Institut Agama Islam Palangka \\ Raya, Jalan Obos G., Palangka Raya, Kalimantan Tengah 74874, Indonesia \\ "email: noor.hujjatusnaini@iain-palangkaraya.ac.id.
}

\begin{abstract}
Analysis of Online Learning Management Based on WhatsApp Social Media to Increase Motivation and Student Learning Outcomes of Digestive System Material. This research is a quantitative descriptive study. The research sample were 58 students at SMPN-1 Mentaya Hilir Utara, Kotawaringin Timur Regency. The learning management instrument used an assessment questionnaire for planning, organizing, implementing, and evaluating learning which was assessed by 4 observers. learning outcomes were analyzed using classical assumption tests consisting of normality tests and homogeneity tests, as well as hypothesis testing using the Paired sample T test and Independent sample T test. The results of the study found that the management of online learning based on whatsApp social media was carried out "good" and the learning motivation of students was in the "medium" category. Online learning based on whatsApp social media has a significant effect on improving the learning outcomes of students' digestive system material, so it can be recommended as an alternative learning model during a pandemic.
\end{abstract}

Keywords: learning management, learning motivation, whatsapp media social

Abstrak: Analisis Manajemen Pembelajaran Online Berbasis Media Sosial WhatsApp Untuk Meningkaykan Motivasi dan Hasil Belajar Siswa Materi Sistem Pencernaan. Penelitian ini merupakan penelitian deskriptif kuantatif dengan sampel 58 siswa di SMPN-1 Mentaya Hilir Utara Kabupaten Kotawaringin Timur. Instrumen manajemen pembelajaran menggunakan angket penilaian perencanaan, pengorganisasian, pelaksanaan, dan evaluasi pembelajaran yang dinilai oleh 4 orang observer. Hasil belajar dianalisis data menggunakan uji asumsi klasik yang terdiri dari uji normalitas dan uji homogenitas, serta uji hipotesis dengan uji statistik Paired sample $\mathrm{T}$ test dan Indipendent sample $\mathrm{T}$ test. Hasil penelitian menemukan bahwa manjemen pembelajaran online berbasis media sosial whatsApp terlaksana "baik" dan motivasi belajar peserta didik dalam kategori "sedang". Pembelajaran online berbasis media sosial whatsApp berpengaruh signifikan terhadap peningkatan hasil belajar materi sistem pencernaan peserta didik, sehingga dapat direkomendasikan sebagai model pembelajaran alternatif di masa pandemi.

Kata kunci: manajemen pembelajaran, motivasi belajar, media sosial whatsApp 


\section{PENDAHULUAN}

Pelaksanaan proses pembelajaran di masa pandemi Covid-19 berdampak yang sangat signifikan pada sistem pembelajaran peserta didik (Hartley, 2020; Adib, 2020). Kebijakan Pemerintah dalam pelaksanaan pendidikan selama masa pandemi Covid-19 adalah melalui metode belajar dari rumah (learn from home), baik menggunakan pendekatan penugasan ataupun pembelajaran online secara mandiri. Pembelajaran online merupakan pembelajaran yang dilakukan dalam jarak jauh melalui media internet dan alat penunjang lainnya seperti telepon seluler dan komputer (Minanti, 2020; Wahyu, 2020). Metode pembelajaran dilaksanakan dengan sistem tanpa tatap muka secara langsung antara guru dan peserta didik, di mana perkembangan teknologi informasi berperan penting sebagai media pembelajaran, salah satunya dengan menggunakan e-learning (Hartanto, 2002; Aan, 2020).

Pelaksanaan pembelajaran online membutuhkan motivasi dan minat belajar peserta didik yang besar, agar tujuan pembelajaran dapat tercapai (Sardiman, 2014; Hilna, 2020). Motivasi belajar menjadi salah satu faktor keberhasilan pembelajaran, dengan harapan dapat mencapai tujuan dan ketuntasan hasil belajar peserta didik. Peserta didik yang memiliki motivasi tinggi memiliki kecenderungan lebih positif dalam pembelajaran (Sardiman, 2014). Oleh karena itu, upaya peningkatan motivasi belajar peserta didik dalam pembelajaran online penting untuk dilakukan. Guru dituntut memiliki aksesibilitas, konektivitas, fleksibilitas, dan kemampuan untuk memunculkan berbagai jenis interaksi selama pembelajaran (Rosen, 2013; Albitar, 2020), harus memastikan kegiatan belajar mengajar tetap berjalan melalui metode pembelajaran yang dipilih (Marjuni, 2019; Vinnafatun, 2015), dituntut mampu mendesain media pembelajaran yang sesuai dengan pembelajaran online (Saifullaoh \& Darwis, 2020).

Latjuba (2019) melaporkan beberapa media sosial yang umumnya dipakai dalam sistem pembelajaran online seperti whatsApp, telegram, instagram, aplikasi zoom ataupun media lainnya sebagai media pembelajaran. Penggunaan pembelajaran online dengan media smartphone diibaratkan "bak sebuah mata pedang" dalam keberhasilan pendidikan. Beberapa hasil penelitian penggunaan smartphone di kalangan pelajar berpotensi mendukung sekaligus berpengaruh negatif pada keberhasilan akademik, bahkan menunjukkan rendahnya kinerja akademis (Rosen, 2013; Lepp, 2015; Chen \& Yan, 2016; Hartley, 2020). Akan tetapi, kondisi pandemi sekarang ini, penggunaan media sosial sebagai salah satu media pembelajaran menjadi pilihan utama. Penggunaan media sosial whatsApp diantaranya dapat digunakan dengan mengkombinasikannya dengan penugasan materi pembelajaran yang dilakukan secara mandiri di rumah.

Berdasarkan hasil observasi pada 114 orang peserta didik di SMP Negeri-1 Mentaya Hilir Utara Kabupaten Kotawaringin Timur diketahui bahwa 70\% peserta didik yang kurang memahami apa yang disampaikan guru, di mana sebanyak $30 \%$ peserta didik memiliki "low motivation", $30 \%$ memiliki motivasi "medium motivation" dan $40 \%$ peserta didik memiliki "high motivation" pada pembelajaran online. Kondisi lingkungan turut mempengaruhi motivasi dan minat belajar yang pada akhirnya berkorelasi pada rendanya hasil belajar peserta didik. Oleh karena itu, aspek motivasi dan keberhasilan kemampuan kognitif peserta didik pada beberapa konsep materi yang sifatnya abstrak menjadi point penting untuk diteliti, dengan harapan dapat tercapainya tujuan dan ketuntasan hasil belajar.

Tuntutan utama keberhasilan pembelajaran menjadi tugas utama guru. Guru harus mampu melakukan beragam inovasi model. media, dan strategi pembelajaran. Hal ini 
menjadi temuan utama dalam tulisan ini, di mana keterlaksanaan dan manajerial proses pembelajaran online berbasis media whatsApp akan menjadi gambaran metode pembelajaran online yang tepat selama pandemi Covid-19 ini. Manajemen proses pembelajaran yang inovatif dengan cara mengkombinasikannya dengan media tertentu diharapkan dapat menjawab tantangan ketersediaan sumber belajar variatif di masa pandemi (Lepp, 2015; Hujjatusnaini, 2020). Lebih lanjut, Hujjatusnaini (2020) menegaskan bahwa metode pembelajaran mix method menjadi pilihan utama yang dapat dijadikan pendekatan pembelajaran alternatif untuk menyampaikan materi-materi yang abstrak dalam sains. Pemberian tugas terstruktur kepada peserta didik yang didukung dengan penguatan penting lainnya dari guru menjadi tambahan solusi.

Manajemen kelas pada pembelajaran online menjadi tantangan bagi guru dalam menciptakan pembelajaran yang menarik dan menyenangkan, menciptakan ruang belajar yang seluas-luasnya bagi peserta didik dan mampu terlibat aktif selama proses pembelajaran berlangsung. Manajemen proses pembelajaran meliputi perencanaan (planning), pengorganisasian (organization), pelaksanaan (implementation), dan evaluasi (evaluation) proses pembelajaran (Syafaruddin, 2005; Aan, 2020) Target akhir yang menjadi temuan dalam penelitian ini adalah gambaran manajerial pembelajaran online berbasis media sosial whatsApp dalam menumbuhkan motivasi belajar peserta didik, dengan harapan dapat berkorelasi positif terhadap capaian hasil belajar.

\section{METODE}

Penelitian ini menggunakan metode deskriptif kuantitatif. Penelitian deskriptif digunakan dalam eksploratif data manajemen proses pembelajaran online guru yang berbasis media sosial whatsApp melalui pendekatan studi deskriptif analitik (Moleong, 2010). Metode deskriptif dalam konteks ini peneliti adalah sebagai instrument kunci, dan teknik pengumpulan data dilakukan dengan cara triangulasi sumber, analisis data bersifat induktif kualitatif, dan data deskriptif penelitian lebih pada makna generalisasi (Rokhman, 2014). Instrumen observasi berupa angket penilaian perencanaan pembelajaran yang dinilai oleh 4 orang observer. Teknik pengumpulan data menggunakan wawancara observasi dan dokumentasi. Data dianalisis dengan deskriptif analysis melalui proses reduksi data, penyajian data, serta verifikasi dan penarikan kesimpulan (Moleong, 2010).

Metode kuantatif digunakan dalam menggali data motivasi dan hasil belajar peserta didik. Sampel penelitian adalah 58 orang peserta didik SMP Negeri-1 Mentaya Hilir Utara Kabupaten Kotawaringin Timur, sebanyak 29 orang peserta didik kelas VIII/R-1 sebagai kelompok kontrol dan 29 peserta didik kelas VIII R-3 sebagai kelompok eksperimen. Instrumen penelitian berupa lembar angket pemanfaatan media sosial whatsApp, lembar angket motivasi belajar IPA, lembar soal hasil belajar kognitif. Teknik pencuplikan sampel yang digunakan adalah cluster sampling, di mana sampel dipilih dari kelompokkelompok unit yan kecil secara acak. Teknik analisis data motivasi dengan menggunakan skala Likert, sedangkan data hasil belajar menggunakan uji asumsi klasik yang terdiri dari uji normalitas dan uji homogenitas, serta uji hipotesis dengan uji statistik Paired sample $\mathrm{T}$ test dan Indipendent sample $\mathrm{T}$ test.

Data motivasi belajar dianalisis dengan menggunakan rumus:

$$
\text { Motivasi } \quad=\frac{\text { Jumlah Seluruh Skor Yang Diperoleh }}{\text { Total Responden } \mathrm{x} \text { Seluruh Soal Sikap }}
$$


Kategori tafsiran nilai motivasi belajar dalam bentuk data interval yang disajikan pada Tabel 1.

Tabel 1. Nilai NGain dan Klasifikasi/Efektifitas

\begin{tabular}{cc}
\hline Interval & Keterangan \\
\hline $80-100$ & Sangat baik \\
$60-79,9$ & Baik \\
$40-59$ & Cukup \\
$20-39$ & Kurang \\
$0-19,9$ & Kurang baik \\
\hline
\end{tabular}

Tafsiran kategori indeks persentase $(\%)$ motivasi belajar dalam bentuk interval persentase disajikan pada Tabel 2. Hasil belajar dikatakan meningkat jika hasil posttest $\left(X_{2}\right)$ mahasiswa lebih tinggi daripada hasil dari pretes $\left(X_{1}\right)$ atau $\left(X_{2}>X_{1}\right)$. Nilai $N$-gain merupakan data perbedaan antara posttest dan pretest, sebagaimana disajikan dalam rumus berikut.

Tabel 2. Indeks Presentase

\begin{tabular}{cc}
\hline Indeks Persentase $(\%)$ & Kategori \\
\hline$\geq 90 \%$ & Sangat Tinggi \\
\hline $70 \%-89.99 \%$ & Tinggi \\
\hline $50 \%-69.99 \%$ & Sedang \\
\hline $30 \%-49.99 \%$ & Rendah \\
\hline$\leq 29.99 \%$ & Sangat Rendah \\
\hline
\end{tabular}

$$
N \text { gain }=\frac{S_{\text {post }}-S_{\text {pre }}}{S_{\text {maks }}-S_{\text {pre }}}
$$

Tabel 3. Nilai NGain dan Klasifikasi/Efektifitas

\begin{tabular}{ccc}
\hline Kualitas & $\mathrm{N}_{\text {gain }}$ & Kategori \\
\hline Sangat meningkat & $\mathrm{g} \geq 0,7$ & Tinggi \\
\hline Meningkat & $0,3<\mathrm{g}<0,7$ & Sedang \\
\hline Cukup meningkat & $\mathrm{g} \leq 0,3$ & Rendah \\
\hline
\end{tabular}

Tabel 4. Kategori Tafsiran Efektifitas N-gain

\begin{tabular}{cc}
\hline Presentase $(\%)$ & Tafsiran \\
\hline$>40$ & Tidak Efektif \\
$40-55$ & Kurang Efektif \\
$56-75$ & Cukup \\
$>76$ & Efektif \\
\hline
\end{tabular}

\section{HASIL DAN PEMBAHASAN}

Manajemen Pembelajaran online Berbasis Media Sosial WhatsApp. Untuk mencapai tujuan pembelajaran online dilakukan pengelolaan pelaksanaan pembelajaran, yang diawali dengan penyusunan perangkat pembelajaran yang sesuai. Seluruh perangkat pembelajaran disusun meliputi minggu efektif, program tahunan, program semester, silabus dan rencana pelaksanaan pembelajaran (RPP), yang sebelumnya ditandatangani oleh kepala sekolah.

Perancanaan Pembelajaran Pembelajaran Online Berbasis Media Sosial WhatsApp. Perencanaan pembelajaran dalam penelitian ini dimulai dari kegiatan merumuskan tujuan apa yang akan dicapai oleh suatu kegiatan pengajaran, cara apa yang dipakai untuk menilai tujuan tersebut, materi bahan apa yang akan disampaikan, 
bagaimana cara menyampaikannya, serta alat atau media apa yang diperlukan. Penilaian perencanaan pembelajaran dalam penelitian disajikan dalam Tabel 5.

Tabel 5. Penilaian Perencanaan Pembelajaran

\begin{tabular}{llcrrrrr}
\hline \multirow{2}{*}{ No } & Tahapan & \multicolumn{4}{c}{ Observer } & $\bar{\Sigma}$ \\
\cline { 3 - 6 } & & 1 & 2 & 3 & 4 & 5 & \\
\hline 1 & Identifikasi masalah & 3 & 3 & 3 & 2 & 4 & 3.0 \\
\hline 2 & Perumusan masalah & 2 & 3 & 4 & 3 & 3 & 3.0 \\
\hline 3 & Penetapan tujuan & 3 & 2 & 3 & 2 & 3 & 2.6 \\
\hline 4 & Elaborasi alternatif & 2 & 2 & 3 & 2 & 3 & 2.4 \\
\hline 5 & Pemilihan materi & 4 & 3 & 4 & 4 & 3 & 3.6 \\
\hline 6 & Pemilihan metode & 3 & 4 & 3 & 3 & 4 & 3.4 \\
\hline 7 & Pemilihan media & 2 & 2 & 2 & 3 & 3 & 2.4 \\
\hline 8 & Pemilihan Alat dan instrumen evaluasi & 4 & 4 & 3 & 4 & 4 & 3.8 \\
\hline 9 & Kesiapan rencana pelaksanaan pembelajaran (RPP) & 4 & 4 & 3 & 3 & 3 & 3.4 \\
\hline 10 & Keselaran antara RPP, silabus, program semester, dan tahunan & 4 & 4 & 4 & 4 & 4 & 4.0 \\
\hline & & Rerata & & & & 3.2 \\
\hline
\end{tabular}

Kategori Baik

Berdasarkan Tabel 5 rerata nilai perencanaan pembelajaran sebesar 3.2 atau dalam kategori baik. Secara keseluruhan item penilaian perencanaan dikategorikan baik, kecuali pada indikator penetapan tujuan (2.6=kategori cukup), elaborasi alternatif ( $2.4=$ kategori cukup), dan pemilihan media ( $2.4=$ kategori cukup). Penetapan tujuan dinilai kurang jelas oleh 2 orang observer ( $40 \%$ ), yang sejalan dengan elaborasi alternatif yang dinilai kurang tampak oleh 3 orang observer $(60 \%)$.

Pelaksanaan Pembelajaran Pembelajaran On-line Berbasis Media Sosial WhatsApp. Pelaksanaan pembelajaran online dilakukan dengan menggunakan tiga tahapan kegiatan yaitu kegiatan pembukaan pendahuluan, kegiatan inti, dan kegiatan penutup. Hasil penelitian manajemen pelaksanaan pembelajaran diuraikan secara rinci pada Tabel 6.

Tabel 6. Pelaksanaan Pembelajaran

\begin{tabular}{|c|c|}
\hline Kegiatan & Uraian Hasil Pengamatan \\
\hline Pendahuluan & $\begin{array}{l}\text { 1. Guru melakukan absensi, motivasi dan menyampaikankan tujuan } \\
\text { pembelajaran. } \\
\text { 2. Guru memberikan apersepsi dan apresiasi, dan menyampaikan materi serta } \\
\text { kemampuan target yang dicapai dari pembelajaran. } \\
\text { 3. Guru mengeksplorasi pengalaman peserta didik tentang tema yang akan } \\
\text { disajikan. } \\
\text { 4. Guru menciptakan kesiapan mental dan menarik perhatian peserta didik } \\
\text { secara optimal, dapat fokus pada pelajaran yang akan disajikan. }\end{array}$ \\
\hline b. Kegiatan Inti & $\begin{array}{l}\text { 1. Guru menyampaikan strategi atau metode pembelajaran yang akan } \\
\text { digunakan } \\
\text { 2. Guru menggunakan metode tanya jawab, demonstrasi, pembelajaran } \\
\text { langsung, dan praktek serta penugasan. } \\
\text { 3. Guru memperhatikan semua faktor yaitu tujuan pembelajaran, } \\
\text { karakteristik/jumlah siswa, karakteristik materi, alokasi waktu, dan fasilitas } \\
\text { yang tersedia. } \\
\text { 4. Guru membagi peserta didik dalam kelompok dan memberikan kesempatan } \\
\text { peserta didik untuk aktualisasi diri baik secara mandiri maupun kelompok. } \\
\text { 5. Guru mengaitkan materi pembelajaran dengan fakta dan fenomena dalam } \\
\text { kehidupan dan pencontohan yang factual, serta integrasinya dalam } \\
\text { keagamaan. }\end{array}$ \\
\hline
\end{tabular}




\begin{tabular}{|c|c|}
\hline c. Penutup & $\begin{array}{l}\text { 1. Guru menyimpulkan materi bersama-sama dengan peserta didik } \\
\text { 2. Guru mengevaluasi dengan cara mengajukan pertanyaan terkait materi yang } \\
\text { telah dipelajari, penegasan materi, dan tindak lanjut materi. } \\
\text { 3. Guru menyampaikan materi yang akan dibahas pada pertemuan } \\
\text { selanjutnya, penugasan literasi. } \\
\text { 4. Guru menutup pelajaran dengan salam dan doa }\end{array}$ \\
\hline
\end{tabular}

Pembelajaran online dan pencapaian tujuan pembelajaran yang ditunjukkan pada Tabel 6 menunjukkan manajemen pembelajaran yang cukup efektif, didukung dengan perencanaan dan pelaksanaan pembelajaran yang jelas. Keterlaksanaan dan efektifitas pembelajaran sangat dipengaruhi oleh kemampuan guru dalam manajemen, meliputi manajemen waktu, manajemen kelas, dan manajemen pembelajaran.

Evaluasi Pelaksanan Pembelajaran On-line Berbasis Media Sosial WhatsApp. Evaluasi pelaksanaan guru dalam pembelajaran online berbasis media sosial WhatsApp dilakukan pada setiap komponen tujuan pembelajaran yang hendak dicapai. Penilaian menggunakan metode tes dan non tes. Model tes meliputi kegiatan praktikum dan tes tertulis (tes tertulis uraian dan objektif), sedangkan metode non tes meliputi pengamatan aktivitas, partisipasi, motivasi, dan etika peserta didik dalam proses pembelajaran. Tes tertulis dilakukan dalam bentuk ulangan harian. Tahapan terakhir dalam proses pembelajaran online berbasis media sosial whatsApp dalam penelitian ini adalah secara keseluruhan dilaksanakan secara online.

Motivasi Belajar Peserta Didik dalam Pembelajaran Online Berbasis Media Sosial WhatsApp. Motivasi belajar peserta didik dalam pembelajaran online berbasis media sosial whatsApp dalam penelitian ini diukur selama proses pembelajaran, yang disajikan dalam Tabel 7.

Tabel 7. Motivasi Belajar Peserta Didik

\begin{tabular}{|c|c|c|c|}
\hline & & Kelas Eksperimen & Kelas Kontrol \\
\hline \multirow{10}{*}{$\begin{array}{l}1 . \\
2 . \\
3 . \\
4 . \\
5 . \\
6 . \\
7 . \\
8 .\end{array}$} & 1. Tekun dalam menghadapi Tugas & $66.34 \%$ & $52.28 \%$ \\
\hline & 2. Ulet dalam Menghadapi Kesulitan Belajar & $74.21 \%$ & $51.17 \%$ \\
\hline & 3. Menunjukkan Minat & $57.52 \%$ & $46.90 \%$ \\
\hline & 4. Senang Bekerja Mandiri & $66.07 \%$ & $48.69 \%$ \\
\hline & 5. Respon terhadap Tugas Rutin & $63.72 \%$ & $49.10 \%$ \\
\hline & 6. Kemampuan Mempertahankan Pendapat & $62.34 \%$ & $48.69 \%$ \\
\hline & 7. Kemampuan Menerima koreksi & $62.48 \%$ & $50.34 \%$ \\
\hline & 8. Kemampuan memecahkan masalah & $70.90 \%$ & $51.17 \%$ \\
\hline & Rerata Indeks Persentase (\%) & $65.45 \%$ & $49.79 \%$ \\
\hline & Kategori Indeks & Sedang & Rendah \\
\hline
\end{tabular}

Data motivasi belajar peserta didik pada materi sistem pencernaan yang dilakukan berbasis media sosial wahatsapp menunjukkan perbedaan antar kelas eksperimen dan kelas kontrol. Perbedaan indeks persentase $(\%)$ tampak motivasi belajar peserta didik pada kelas ekperimen dalam kategori sedang, lebih baik dibandingkan motivasi belajar peserta didik di kelas kontrol dalam kategori rendah.

Hasil Belajar Peserta Didik Pembelajaran Online Berbasis Media Sosial WhatsApp. Data hasil belajar kognitif peserta didik dalam pembelajaran online berbasis media sosial whatsApp pada materi sistem pencernaan dianalisis berdasarkan nilai NGain, yang sebelumnya dilakukan uji normalitas dan homogenitas data berdasarkan Kolmogorov smirnov yang disajikan dalam Tabel 8. 
Tabel 8. Analisis NGain Score Hasil Belajar Peserta Didik

\begin{tabular}{lrr}
\hline & Kelas Eksperimen & Kelas Kontrol \\
\hline Rerata Pre Test & 31.55 & 26.70 \\
Rerata Post Test & 75.24 & 56.66 \\
Mean & 63.56 & 41.21 \\
Minimum & 25.37 & 0.41 \\
Maksimum & 84.62 & 18.79 \\
Normalitas & 0.067 (pre test) & 0.59 (pre test) \\
& 0.70 (post test) & 0.52 (post test) \\
Homogenitas & 0.321 & 0.321 \\
Rerata NGain Score & 0.63 & 57.14 \\
Rerata NGain $(\%)$ & 63.56 & 41.39 \\
Kategori efektifitas & Cukup efektif & Tidak efektif \\
\hline
\end{tabular}

Hasil analisis normalitas data untuk hasil belajar kognitif peserta didik dinyatakan terdistribusi normal, dimana hasil uji normalitas data pada kelas eksperimen dan kelas kontrol sig. > 0.05. Normalitas data didukung dengan uji homogenitas sebesar sig. 0.321 $>0.05$, sehingga diinterpretasikan bahwa varians data baik dikelas eksperimen mauoun kelas kontrol dinyatakan homogen (Tabel 8). Hasil uji normalitas dan homogenitas menjadi indikator kelayakan uji selanjutnya. Hasil analisis NGain (\%) di kelas eksperimen sebesar 63.56 dikategorikan cukup efektif, sedangkan kelas kontrol sebesar 41.39 dikategorikan tidak efektif. Signifikansi pengaruh penerapan pembelajaran online melalui media sosial wahtsapp disajikan pada Tabel 9.

Tabel 9. Paired sample T test

\begin{tabular}{|c|c|c|c|c|c|c|c|}
\hline & \multicolumn{7}{|c|}{. Paired Differences } \\
\hline & & \multirow{3}{*}{ Mean } & \multirow{3}{*}{$\begin{array}{c}\text { Std. } \\
\text { Deviation }\end{array}$} & \multirow{2}{*}{\multicolumn{2}{|c|}{$\begin{array}{l}\text { 95\% Confidence } \\
\text { Interval of the } \\
\text { Difference }\end{array}$}} & \multirow{3}{*}{$\mathrm{t}$} & \multirow{3}{*}{$\begin{array}{l}\text { Sig. (2- } \\
\text { tailed) }\end{array}$} \\
\hline & & & & & & & \\
\hline & & & & Lower & Upper & & \\
\hline $\begin{array}{l}\text { Pair } \\
1\end{array}$ & $\begin{array}{l}\text { Pretes Eksperimen - } \\
\text { Postes Eksperimen }\end{array}$ & -43.68966 & 12.73102 & -48.53228 & -38.84703 & -18.481 & .000 \\
\hline $\begin{array}{l}\text { Pair } \\
2\end{array}$ & $\begin{array}{l}\text { Pretes Kontrol - } \\
\text { Postes Kontrol }\end{array}$ & -29.96552 & 7.17875 & -32.69617 & -27.23487 & -22.479 & .000 \\
\hline
\end{tabular}

Tabel 10. Independent Sample T Test

\begin{tabular}{|c|c|c|c|c|c|c|c|c|}
\hline & & \multicolumn{3}{|c|}{$\begin{array}{l}\text { Levene's Test } \\
\text { for Equality } \\
\text { of Variances }\end{array}$} & \multicolumn{3}{|c|}{ t-test for Equality of Means } & \multirow[b]{2}{*}{$\begin{array}{l}\text { Std. Error } \\
\text { Difference }\end{array}$} \\
\hline & & $\mathrm{F}$ & Sig. & $\mathrm{t}$ & $\mathrm{df}$ & $\begin{array}{l}\text { Sig. (2- } \\
\text { tailed) }\end{array}$ & $\begin{array}{c}\text { Mean } \\
\text { Difference }\end{array}$ & \\
\hline Hasil & $\begin{array}{l}\text { Equal variances } \\
\text { assumed }\end{array}$ & .592 & .445 & -16.966 & 56 & .000 & -43.68966 & 2.57510 \\
\hline Belajar & $\begin{array}{l}\text { Equal variances } \\
\text { not assumed }\end{array}$ & & & -16.966 & 54.978 & .000 & -43.68966 & 2.57510 \\
\hline
\end{tabular}

Hasil uji Paired sample T test (Tabel 9) mempertegas data nilai NGain (Tabel 8) menunjukkan nilai sig.0.000< 0.05, sehingga dapat diinterpretasikan bahwa ada perbedaan rata-rata pre test dan post test hasil belajar peserta didik pada kelas eksperimen dan kelas kontrol selama penerapan pembelajaran online melalui media sosial wahtsapp terhadap hasil belajar, perbedaan rerata hasil belajar tersebut mempertegas bahwa ada pembelajaran online melalui media sosial wahtsapp berpengaruh terhadap hasil belajar 
peserta didik pada materi sistem pencernaan. Klarifikasi homogenitas data hasil belajar terhadap pengaruh perlakuan dalam penelitian dilakukan melalui Independet sample $\mathrm{T}$ test, yang disajikan pada Tabel 10 .

Hasil analisis pada Tabel 10 mengklarifikasi nilai homogenitas varians data pada kelas eksperien dan kelas kontrol ditunjukkan dengan nilai sig. $0.000<0.05$. Peningkatan hasil belajar peserta didik pada materi sistem pencernaan yang dikategorikan cukup efektif diterapkan pada kelas eksperimen dapat dinyatakan sebagai akibat dari pengaruhi penerapan pembelajaran online melalui media sosial wahtsapp.

Manajemen Pembelajaran online Berbasis Media Sosial WhatsApp. Manajemen pembelajaran dalam penelitin ini meliputi proses pengelolaan sumber daya yang digunakan selama pembelajaran online, dengan harapan dapat mencapai tujuan pembelajaran secara efektif dan efisien. Manajemen pembelajaran mutlak dilakukan guru termasuk didalamnya perencanaan, pengelolaan, pelasanaan, dan evaluasi bertujuan untuk dapat mencapai tujuan pembelajaran lebih maksimal, efektif, dan efisien (Suwardi, 2007; Hazal, 2016).

Tahap pertama dalam manajemen pembelajaran adalah perencanan pembelajaran. Perencanaan pembelajaran merupakan point penting yang harus diperhatikan dalam manajemen pembelajaran, dengan tujuan untuk mencapai keberhasilan pembelajaran. Perencanaan pembelajaran dalam penelitian ini dimulai dari kegiatan merumuskan tujuan apa yang akan dicapai kegiatan pengajaran dalam penelitian ini menunjukkan kategori "baik"dengan rerata sebesar 3.2 (Tabel 5). Perencanaan ini tampak dari perumusan cara penetapan tujuan pembelajaran yang jelas, materi bahan apa saja yang akan digunakan dalam menyampaikan materi, bagaimana cara menyampaikannya di dalam kelas secara online, serta alat atau media apa yang digunakan juga terperinci.

Rencana pembelajaran yang berhasil disusun dengan baik menjadi barometer tercapainya tujuan pembelajaran (Albitar, 2020). Perencanaan pembelajaran menjadi pedoman guru dalam melaksanakan tugas sebagai pendidik secara profesional, sebagai langkah awal sebelum proses pembelajaran berlangsung. Perencanaan pembelajaran merupakan penjabaran, pengayaan, dan pengembangan kurikulum, sehingga perumusan tujuan pun harus mengacu pada kurikulum. Tujuan pembelajaran yang dirumuskan harus mengarah pada kualifikasi kemampuan yang harus dicapai oleh peserta didik setelah melakukan proses pembelajaran, sehingga diharapkan terjadinya "perubahan perilaku" (change of behavior) meliputi aspek kognitif, afektif dan pikomotor (Salim, 2015).

Indikator pemilihan media dinilai kurang relevan dan kurang memadai dengan materi yang disampaikan oleh 3 orang observer $(60 \%)$. Ketidaksesuaian pemilihan media berkorelasi dengan perumusan tujuan yang masih kurang jelas. Media berfungsi sebagai visualisasi materi yang sifatnya abstrak dan sulit untuk dipahami secara verbalistik, merangsang pikiran, perasaan, minat, dan perhatian peserta didik. Minat dan ketertarikan peserta didik pada materi menjadi rendah ketika materi terlalu abstrak dan sulit untuk dipahami, sehingga media pembelajaran yang sesuai dan menarik memegang peran penting. Media dapat berbentuk bahan bacaan, video, torso, dan lainnya yang sifatnya menjadi visualisasi obyek yang tidak dapat dihadirkan secara langsung dalam pembelajaran. Media menyamakan persepsi antara guru dan peserta didik, mengatasi keterbatasan ruang dan waktu, serta meminimalisir kemungkinan salah tafsir dalam memahami materi dan informasi (Niken, 2020).

Manajemen waktu dilihat berdasarkan kemampuan guru dalam mengatur jam pelajaran secara online. Pengaturan waktu dalam penugasan pembelajaran online dalam penelitian ini memerlukan waktu yang lebih panjang dibandingkan pembelajaran offline. 
Manajemen kelas dalam penelitian ini guru mengatur kegiatan dan proses pembelajaran melalu media whatsApp group (WAG) yang dilaksanakan melalui chatting dan voice note (Albitar, 2020). Manajemen pembelajaran yang dilakukan guru adalah mengelola situasi dan proses pembelajaran secar online dengan penugasan quiz dan soal. Lebih lanjut Albitar (2020) mempertegas manajemen pembelajaran sangat memerlukan keterampilan guru dalam memberikan variasi dan ritme pembelajaran, sehingga peserta didik tidak bosan dan memiliki motivasi belajar yang lebih baik.

Tahapan selanjutnya dalam manajemen pembelajaran adala evaluasi. Evaluasi, yang harus dilaksanakan secara berkelanjutan. Hasil evaluasi merupakan salah satu indikator keberhasilan tugas guru dalam proses pembelajaran. Penilaian guru dinilai sudah mengikuti penilaian yang disyaratkan dalam kurikulum. Penilaian hasil belaiar dapat dilakukan terhadap program, proses, dan hasil belajar (Mulyasa, 2011). Penilaian juga difungsikan untuk mengetahui aktivitas dan partisipasi peserta didik dalam pembelajaran, pembentukkan kompetensi, kemajuan belajar, mendiagnosis kesulitan belajar, serta memberikan umpan balik untuk memperbaiki proses pembelajaran.

Motivasi Belajar Peserta Didik dalam Pembelajaran Online Berbasis Media Sosial WhatsApp. Variabel lain yang diukur dalam penelitian ini adalah motivasi belajar peserta didik. Manajemen pembelajaran yang baik akan mampu mestimulasi motivasi belajar peserta didik yang lebih baik pula. Data motivasi belajar peserta didik pada materi sistem pencernaan yang dilakukan berbasis media sosial wahatsapp pada Tabel 7 menunjukkan perbedaan yang cukup signifikan antar kelas eksperimen dan kelas kontrol, di mana indeks persentase (\%) pada kelas ekperimen sebesar $65.45 \%$ (kategori sedang), sedangkan motivasi belajar peserta didik di kelas kontrol sebesar $49.79 \%$ (kategori rendah). Perbedaan motivasi belajar peserta didik dipengaruhi oleh banyak hal, diantaranya metode pembelajaran, media pembelajaran yang digunakan, kesiapan perangkat pembelajaran lainnya, kemampuan dasar peserta didik sebelumnya, dan faktor eksternal lain di luar variabel penelitian.

Data manajemen pembelajaran pada Tabel 5 dan Tabel 6 menunjukkan perencanaan dan pelaksanaan pembelajaran yang matang dilakukan guru selaman proses pembelajaran. Kemampuan dasar yang dimiliki peserta didik antara kelas eksperimen dan kelas kontrol setara. Perbedaan metode penugasan yang digunakan pada kedua kelas mempengaruhi stimulasi motivasi belajar (Sabriani, 2012; Aldila, 2013). Metode penugasan di kelas eksperimen menggunakan penugasan terstruktur resitasi, sedangkan kelas kontrol menggunakan penugasan dalam bentuk Pekerjaan Rumah (PR). Lebih lanjut Sabriani (2012) menegaskan bahwa tugas terstruktur mampu meningkatkan motivasi belajar yang lebih baik, di mana pemberian tugas resitasi merupakan perluasan dari bentuk penugasan berbentuk PR. Metode penugasan terstruktur resitasi memberikan kesempatan peserta didik untuk menganalisis dan mempertanggungjawabkan penugasan yang diberikan guru, baik secara berkelompok ataupun mandiri. Pembelajaran online berbasis media sosial whatsApp dalam penelitian ini tidak mampu menstimulasi minat belajar yang lebih baik, baik di kelas eksperimen maupun kelas kontrol (Tabel 6). Hal ini dipengaruhi penerimaan atau respon pada penugasan yang diberikan guru yang juga tidak lebih baik.

Hasil Belajar Peserta Didik Pembelajaran Online Berbasis Media Sosial WhatsApp. Kemandirian belajar mempengaruhi pemahaman konsep, keterampilan intelektual, motoric, dan sikap peserta didik (Zubaidah, 2002). Aspek-aspek tersebut merupakan bagian dari hasil belajar. Keterampilan intelektual merupakan kemampuan melakukan aktivitas kognitif, meliputi pemahaman konsep dan penggunaan kaidah dalam 
pemecahan masalah. Fakta ini sejalan dengan capaian motivasi belajar pada aspek keuletan peserta didik dalam menghadapi kesulitan belajar (74.21\%), dan kemampuan memecahkan masalah yang diberikan guru dalam pembelajaran online $(70.90 \%)$ dalam kategori tinggi (Tabel 7). Ketercapaian variabel penelitian ini sejalan dengan data hasil belajar kognitif peserta didik pada Tabel 8 .

Tabel 8 menunjukkan data bahwa pembelajaran online berbasis media sosiap whatsApp mampu meningkatkan hasil belajar kognitif peserta didik, di mana rerata NGain (\%) kelas eksperimen (63.56\%) lebih besar dibandingkan kelas kontrol (41.39\%). Nilai NGain (\%) kelas iinterpretasikan dalam kategori cukup efektif dalam meningkatkan hasil belajar di kelas eksperimen, dibandingkan kelas kontrol. Efektifitas hasil belajar dipengaruhi oleh metode pembelajaran online yang diberikan guru, dibuktikan dengan nilai signifiknasi uji Paired sample $\mathrm{T}$ test (Tabel 9). Signifikansi tersebut diperkuat dengan uji Independet sample $\mathrm{T}$ test pada Tabel 10 yang mempertegas bahwa pembelajaran online berbasis media sosial whatsApp pada materi sistem pencernaan berpengaruh signifikan terhadap hasil belajar kognitif peserta didik. Kemampuan belajar kognitif menjadi tolak ukur keberhasilan belajar yang utama dinilai guru, karena menjadi indikator pemahaman jangka panjang peserta didik, menjadi dasar dalam mengkonstruk pemahaman dan pemaknaan terhadap materi, dan dasar dalam keterampilan menganalisis dan keterampilan berpikir (Arif, 2005). Temuan dalam penelitian ini mempertegas potensi pembelajaran berbasis media sosial whatsApp melalui penugasan terstruktur sebagai alternatif pembelajaran online di masa pandemi.

\section{SIMPULAN}

Pembelajaran online berbasis media sosial whatsApp dalam penelitian ini dapat disimpulkan dapat meningkatkan motivasi dan hasil belajar kognitif peserta didik melalui penugasan materi sistem pencernaan. Manjemen pembelajaran online berbasis media sosial whatsApp terlaksana "baik" dan motivasi belajar peserta didik dalam kategori "sedang". Pembelajaran online berbasis media sosial whatsApp berpengaruh signifikan terhadap peningkatan hasil belajar materi sistem pencernaan peserta didik, sehingga pembelajaran berbasis media sosial whatsapp melalui penugasan terstruktur dapat menjadi salah satu model pembelajaran online alternatif dalam masa pandemi.

\section{DAFTAR RUJUKAN}

Aan Widiyono. (2020). Efektifitas Perkuliahan Daring (Online) pada Mahasiswa PGSD di Saat Pandemi Covid 19. Jurnal Pendidikan, 8(2), 169-177.

Adib Rifqi, S. (2020). Lembar Kegiatan Literasi Saintifik Untuk Pembelajaran Jarak Jauh Topik Penyakit Coronavirus 2019 (Covid-19). Jurnal Edukatif..2(1): 28-37.

Ahmad, Salim. (2015). "Manajemen Pendidikan Karakter di Madrasah (Sebuah Konsep dan Penerapannya)." Tarbawi, 1: 1-16

Albitar Syarifudin, Septian, Albitar. (2020). Impelementasi Pembelajaran Daring Untuk Meningkatkan Mutu Pendidikan Sebagai Dampak Diterapkannya Social Distancing." Metalingua, Jurnal Pendidikan, 5 (1): 31-34.

Aldila, herman, dan Mulyanratna. (2013). Pengaruh Pemberian Tugas Terstruktur dalam Model Pembelajaran Kooperatif Tipe STAD Terhadap Hasil Belajar Sisw Pada Materi Fluida Statis di Kelas XI IPA SMA Negeri 1 Maospati. Jurnal Inovasi Pendidikan Fisika. 2(2): 49-54. 
Arif Sidharta. (2005). Model Pembelajaran Asam Basa Berbasis Inkuiri Laboratorium Sebagai Wahana Pendidikan Sains Siswa SMP. Jurnal Penelitian Pendidikan. 13(2): 32-56.

Chen, Q., \& Yan, Z. (2016). Does Multitasking with Mobile Phones Affect Learning? A Review. Computers in Human Behavior. 54: 34-42. https://doi.org/10.1016/J.CHB.2015.07.047.

Dewi, Wahyu Aji Fatma. (2020). "Dampak Covid-19 Terhadap Implementasi Pembelajaran Daring di Sekolah Dasar.” Edukatif:Jurnal Ilmu Pendidikan, 2(1): 55-61.

Hartanto, W. (2002). Penggunaan E-Learning Sebagai Media Pembelajaran. Jurnal Pendidikan Ekonomi. 10(1): 1-18.

Kendall Hartley. Bendixen, L. D., Olafson, L., Gianoutsos, D., \& Shreve, E. (2020). The Smartphone in Self-Regulated Learning and Student Success: Clarifying Relationships and Testing an Intervention. International Journal of Educational Technology in Higher Education 17(52): 2-14 https://doi.org/10.1007/s10639020-10179-3.

Hazal Fitri. (2016). Manajemen Pelaksanaan Pembelajaran ICT di SD Negeri 46 Kota Banda Aceh. Visipena, 7(2): 184-196. http://doi.org/10.46244/visipena.v7/i2.232.

Lepp, A., Barkley, J. E., \& Karpinski, A. C. (2015). The Relationship between Cell Phone Use and Academic Performance in a Sample of U.S. College Students. SAGE Open, 5(1), 2158244015573169. https://doi.org/10.1177/2158244015573169.

Marjuni \& Hamzah Harun. (2019). Penggunaan Multimedia Online dalam Pembelajaran, Jurnal Manajemen Pendidikan: Idaarah. 3(2): 194-204.

Moleong, Lexy J. (2010). Metodologi Penelitian Kualitatif Edisi Revisi. Bandung: Remaja Rosdakarya.

Mulyana. (2008). Metodelogi Penelitian Kualitatif. Bandung: Remaja Rosdakarya.

Mulyasa, E. (2009). Menjadi Guru Profesional, Menciptakan Pembelajaran Kreatif dan Menyenangkan. Bandung: Remaja Rosdakarya.

Mulyasa. (2011). Manajemen Pendidikan Karakter. Jakarta: PT Bumi Aksara.

Niken S.H. Andi Thahir. Ahmad Fauzan. (2020). Manajemen Program Penguatan Pendidikan Karakter Melalui Pembelajaran Daring dan Luring di Masa Pandemi Covid 19-New Normal Journal of Islamic Education Management. 6 (2): 97-116.

Noor Hujjatusnaini. Meliyani. Yuliandari. Iis Yulianti. Noor Y. S. Nur Istiqomah. (2020). Analisis Pola Hubungan antara Gaya Belajar, Karalkteristik dan Multiple intelengence Mahasiswa pada Pembelajaran Biologi Terintegrasi Fenomena Coronavirus-19. Jurnal Bioterdidik. 8(3): 76-83.

Putria, Hilna; Luthfi Hamdani Maula; Din Azwar Uswatun. (2020). “Analisis Proses Pembelajaran dalam Jaringan (DARING) Masa Pandemi COVID-19 Pada Guru Sekolah Dasar." Jurnal Basicedu, 4(4): 861-72. https://doi.org/10.31004/basicedu.v4i4.460.

Rokhman, Fathur, M Hum, and Ahmad Syaifudin. (2014). "Character Education For Golden Generation 2045 (National Character Building for Indonesian Golden Years)." Procedia - Social and Behavioral Sciences. 141: 1161-65.

Rosen, L. D., Carrier, L. M., \& Cheever, N. A. (2013). Facebook and texting made me do it: Media-induced task-switching while studying. Computers in Human Behavior. 29(3), 948-958. https://doi.org/10.1016/J.CHB.2012.12.001. 
Saifulloh dan Mohammad Darwis. (2020). Manajemen Pembelajaran dalam Meningkatkan Efektifitas Proses Belajar Mengajar di Masa Pandemi Covid-19. Bidayatuna. 3(2): 286-311

Sardiman.A.M. (2014). Interaksi dan Motivasi Belajar Mengajar. PT. Raja Grafindo Persada, Jakarta.

Siti Sabriani. (2012). Penerapan Pemberian Tugas Terstruktur disertai Umpan Balik Pada Pembelajaran Langsung Untuk Meningkatkan Motivasi dan Hasil Belajar Siswa (Studi Pada Materi Pokok Struktur Atom Kelas X6 SMA Negeri 3 Watampoe. Jurnal Chemica. 12(2): 39-46.

Siti Zubaidah. (2012). Beberapa Alternatif Pembelajaran Untuk Meningkatkan Pemahaman Terhadap Istilah atau Konsep Biologi. Jurnal Pendidikan dan Pembelajaran Universitas Negeri Malang. 9(1): 23-24.

Sofyana Latjuba \& Abdul Rozaq. (2019). Pembelajaran Daring Kombinasi Berbasis WhatsApp Pada Kelas Karyawan Prodi Teknik Informatika Universitas Pgri Madiun.” Jurnal Nasional Pendidikan Teknik Infromatika. 8(1): 81-86.

Suwardi. (2007). Manajemen Pembelajaran. Surabaya: Media Grafika.

Syafaruddin. (2005). Manajemen Lembaga Pendidikan Islam. Jakarta: Ciputat Press.

Vinnafatun. Fathorrahman. Mochamad Bukhori. (2019) Gaya Kepemimpinan, Budaya, Dan Kompetensi Terhadap Kepuasan Kerja dan Kinerja Guru SMP Swasta Islam. Jurnal Bisnis dan Ekonomi Asia. 15(1): 52-72.

Yanti, Minanti, T. Eko Kuntarto. Agung Rimba Kurniawan. (2020). Pemanfaatan Portal Rumah Belajar Kemendikbud Sebagai Model Pembelajaran Daring di Sekolah Dasar." Adi Widya : Jurnal Pendidikan Dasar, 5(4): 61-68. 